\title{
PMMA 樹脂の引張破壊挙動に及ぼす動的効果†
}

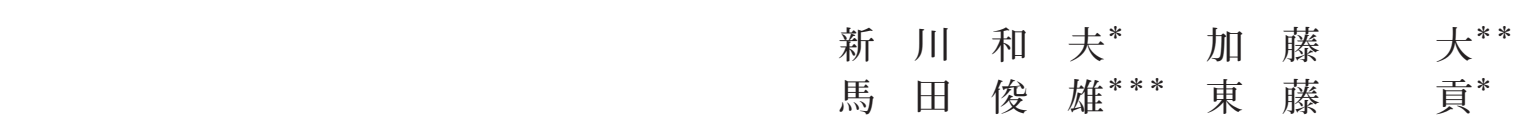

Dynamic Effect on Impact Tensile Fracture Behavior of PMMA Resin

by

\author{
Kazuo Arakawa ${ }^{*}$, Masaru Kato ${ }^{* *}$, Toshio MadA ${ }^{* * *}$ and Mitsugu Todo *
}

The fracture behavior of a brittle polymer, polymethyl methacrylate(PMMA) resin, under static and impact tensile loadings was studied using single-edge-cracked specimens. The impact load and displacement were measured with a Piezo sensor and a high-speed extensometer, respectively. The load and displacement diagram, i.e., the external work $U_{\text {ex }}$ applied to the specimen was used to determine the elastic energy $E_{\mathrm{e}}$ and non-elastic energy $E_{\mathrm{n}}$ due to viscoelastic and plastic deformation, and the fracture energy $E_{\mathrm{f}}$ for creating new fracture surface $A_{\mathrm{s}}$. The energyrelease rate was then estimated using $G_{\mathrm{f}}=E_{\mathrm{f}} / A_{\mathrm{s}}$. The values of $E_{\mathrm{e}}, E_{\mathrm{n}}, E_{\mathrm{f}}$ and $G_{\mathrm{f}}$ were correlated with the fracture loads, and the two results determined for the static and impact loadings were compared to study the effect of loading conditions.

Key words : Polymer, PMMA resin, Static and impact loadings, Tensile fracture, Fracture energy, Elastic energy, Fracture load, External work, Energy release rate, High-speed extensometer

\section{1 緒言}

近年, 軽量化が要求される部材として, 比重が小さい 高分子材料が多く使用されるようになっている。しかしな がら材料の機械的特性，とくに耐衝撃性がまだ十分では なく，その改善が重要な課題となっている。 そのため種々 の条件下で破壊挙動が調べられ，材料の力学的な信頼性 が評価されている.1)例えば静的な条件下では, 試験片に 作用する荷重と変位が計測され，き裂寸法などの条件か ら破壊じん性值などが得られている.1)また衝撃条件下でも 破壊じん性值が計測され，静的条件下との比較検討がな されている。一般に, 多くの高分子材料は粘弾性挙動を 呈し，その結果，負荷速度依存性が発生する。さらに， き裂が高速度で進展するぜい性破壊では，材料の変形に 伴う慣性力や運動エネルギが無視できず, 動的効果を考 慮しなければならないことが指摘されている.2) 7)この動 的効果の計測法として, 光弾性法 ${ }^{3)}$, 4) やコースティック 法 5) 7)が応用され, き裂周辺の動的応力場が評価されて いる。そして動的破壊じん性值が導かれ，き裂速度との 対応関係などが調べられている。ところが粘性や動的効 果を定量的に評価することは技術的に容易でなく，破壊 挙動に及ぼすこれらの効果はほとんど考察されていない のが現状である。

本研究では, 汎用的な高分子材料であるメタクリル (PMMA) 樹脂を用いて，ぜい性破壊挙動に及ぼす粘性 や動的効果を定量的に評価することを試みた。その計測 法として，筆者らが開発した静的および衝撃引張装置を

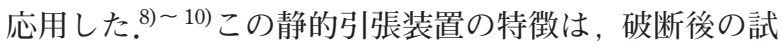

験片の運動を拘束しないため負荷方向への飛しょうが可 能となること, これにより試験片に蓄積された弾性エネル ギを評価することが可能となる，また，光ファイバを用い た変位計により，き裂近傍の静的および動的変位が精度 良く計測できることである.8), 9)一方, 衝撃引張装置の特 徴は, ピエゾセンサによる衝撃荷重計測 ${ }^{10)}$ 光ファイバに よるき裂近傍の高速度変位が計測できることである。本 研究では, 上述の静的打よび衝撃引張装置を用いて, 荷 重と変位を計測した。荷重と変位より外力仕事 $U_{\mathrm{ex}}$, 破 断直後の残留変位より非弾性エネルギ $E_{\mathrm{n}}$ を求めた。静 的負荷実験では試験片の破断後の飛しょう高さより，衝 撃負荷実験では試験片の破断直後の振幅より弾性エネル ギ $E_{\mathrm{e}}$ を決定した。 $U_{\mathrm{ex}}, E_{\mathrm{n}}, E_{\mathrm{e}}$ より破壊エネルギ $E_{\mathrm{f}}$ を求 め, エネルギ比 $E_{\mathrm{e}} / U_{\mathrm{ex}}, E_{\mathrm{n}} / U_{\mathrm{ex}}, E_{\mathrm{f}} / U_{\mathrm{ex}}$ を評価した。さ らに破面の面積 $A_{\mathrm{s}}$ を用いて, エネルギ解放率を $G_{\mathrm{f}}=$ $E_{\mathrm{f}} / A_{\mathrm{s}}$ で求め, 破断荷重 $P_{\mathrm{c}}$ との対応関係を検討した。 そ して, PMMA 樹脂のぜい性破壊挙動に及ぼす粘性や動 的効果を考察した。

\section{2 実 験 方 法}

\section{$2 \cdot 1$ 試験片}

試験片として板厚 $3 \mathrm{~mm}$ の PMMA (Sumipex E) 樹脂板 を用いた. Fig. 1 に形状, 寸法を示す。試験片の片側中 央部に切欠きを導入し, その先端部をカミソリで鋭くし た。 ただし試験片の破断荷重 $P_{\mathrm{c}}$ および外力仕事 $U_{\mathrm{ex}}$ を変 化させるため, 異なる長さ $1.5 \sim 5 \mathrm{~mm}$ の切欠きを導入 した。さらに試験片の両端には直径 $6 \mathrm{~mm}$ の穴をあけ, ピン負荷用とした。

$\dagger$ 原稿受理 平成 19 年 8 月 17 日 Received Aug. 17, 2007 @ 2008 The Society of Materials Science, Japan

* 正会員 九州大学応用力学研究所 = 816-8580 春日市春日公園, Res. Inst. Appl. Mech., Kyushu Univ., Kasuga-koen, Kasuga, 816-8580

** 九州大学大学院 干816-8580 春日市春日公園, Graduate Student, Kyushu Univ., Kasuga-koen, Kasuga, 816-8580

$* * *$ 九州大学応用力学研究所 $=816-8580$ 春日市春日公園, Res. Inst. Appl. Mech., Kyushu Univ., Kasuga-koen, Kasuga, 816-8580 


\section{$2 \cdot 2$ 静的引張試験}

Fig. 2 に静的引張試験法の概略を示す。試験片の下部 は固定し，上部を鋼製のグリップとピンを用いることに より引張負荷を加えた。引張速度は $1 \mathrm{~mm} / \mathrm{min}$ とし, 室 温下で実験を行った。な損荷装置として，インストロ ン形引張試験機を用いた。試験片上端部の負荷ジグは, 鋼製の丸棒 4 本で構成されている。このジグの特徴は破 断後に試験片の運動を拘束しないこと，そのため負荷方 向への飛しょうが可能となる。吕, 9) さらにPMMA 試験片に 比べて岡性が十分高いため, ジグに蓄積されるエネルギが 無視できることである。試験片の飛しょう高さは，丸棒

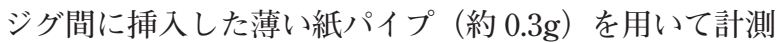
した。この紙パイプは破断した試験片部（約 $30 \mathrm{~g}$ ）ととも に飛しょうし，最大高さで停止するように設定されてい る。最大高さを計測することにより，試験片に蓄積され た弾性エネルギを求めた。ただし紙パイプの質量とジグ 間との摩擦は無視できる程度の小さいものと仮定した。

変位計測法の概略を同困に示す。ピン負荷部の変位は, 試験機のクロスヘッドの移動量より求めた。一方，き裂 近傍の変位 $\delta$ の計測には高速度変位計を利用した.8), 9) こ の変位計では，光ファイバを試験片に貼り付け，その移 動量を PSD (Position Sensing Detector) センサで計測す る。センサからの出力波形はアンプで増幅した後, デジ タルメモリで記録した。このセンサは約 $100 \mathrm{kHz}$ の応答 速度を有しており，静的打よび動的変位計測に使用可能 である.8), 9)なお高速き裂進展による影響を避けるため， 光ファイバを切欠きから $3 \mathrm{~mm}$ 離れた下部に貼り付けた。 ただしこれによる変位の計測䛊差は数％以下であり，実 験解析では無視することとした。

\section{$2 \cdot 3$ 衝撃引張試験}

Fig. 3 に衝撃引張試験法の概略を示す。本研究では, 重錘の自由落下を利用した衝撃引張装置 ${ }^{10)}$ を使用した。 この装置は，(1) 重錘を任意の高さ位置で固定する電磁 石，(2) 試験片を固定する軸，(3) 圧縮を引張りに変換
する金属枠，（4）衝撃荷重を計測するためのピエゾセン サから構成されている.

本研究では，重錘として質量 $10 \mathrm{~kg}$ ，金属枠の上端か ら重鍾までの高さを $300 \mathrm{~mm}$ とした。このとき衝撃時の 重錘の速度は約 $2.4 \mathrm{~m} / \mathrm{s}$ となる。また金属枠の上端に厚 さ $3 \mathrm{~mm}$ のゴムシートを貼付けた。これにより衝撃時に 発生する高周波振動を軽減することができる，このピエ ゾセンサは $45 \mathrm{kHz}$ の周波数特性を有しており，動的計測 が可能である.10)なお変位計測は，切欠きから $3 \mathrm{~mm}$ 離れ た上部に光ファイバを貼り付けることにより行なった。

\section{3 実験結果および考察}

\section{$3 \cdot 1$ 静的 $\boldsymbol{P}-\delta$ 関係}

Fig. 4 に静的引張試験で得られた荷重 $P$ と変位 $\delta$ の計 測例を示す．ここでは破断時の荷重を $P_{\mathrm{c}}$, 変位を $\delta_{\mathrm{c}}$ で 表示した。 $P$ と $\delta$ は負荷時間 $t$ とともに増加し, 試験片 が破断すると $P_{\mathrm{c}} ， \delta_{\mathrm{c}}$ から急激に低下した。ここで注目す べきことは， $P$ と $\delta$ の勾配が $t$ と共に変化すること，ま た破断後に残留変位 $\delta_{\mathrm{n}}$ が生じたことである。これは静的 引張試験では, PMMA 樹脂の粘性による非弾性効果が 無視できないことを示唆している.

本研究では，上述の非弾性効果を詳細に調べるため, 破断直後の試験片の残留変位 $\delta_{\mathrm{n}}$ を計測した。このため PSD センサからの出力波形をサンプリングタイム $10 \mathrm{~ms}$ と $1 \mu \mathrm{s}$ 間隔の 2 種類で記録した (Figs. 4, 5 参照). Fig. 5 の結果で明らかなことは， $\delta_{\mathrm{c}}$ で急激に低下し，その後は 減衰を伴いながら振動したことである。

荷重 $P$ と変位 $\delta$ の計測值（Fig. 4 参照） から静的 $P-\delta$ 関係を求めた。その結果例を Fig. 6 に示す。ここで注目 すべきことは，非弾性効果が見かけ上顕著ではなく，P- $\delta$ 関係が線形的に表示されていることである。

\section{$3 \cdot 2$ 動的 $\boldsymbol{P}^{\prime}-\delta^{\prime}$ 曲線}

Fig. 3 の衝撃引張試験機を用いると, 試験片には静的 な初期荷重 $P_{0}(=0.13 \mathrm{kN})$ が作用し，そのあと衝撃荷重 $P$ が作用する。変位 $\delta$ も同様に，初期変位 $\delta_{0}$ と動的変位

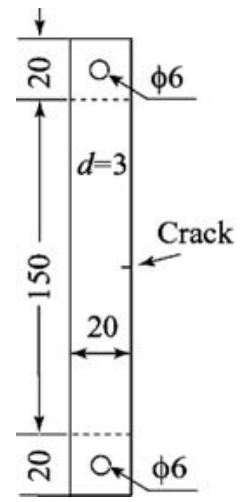

Fig. 1 Specimen geometry.

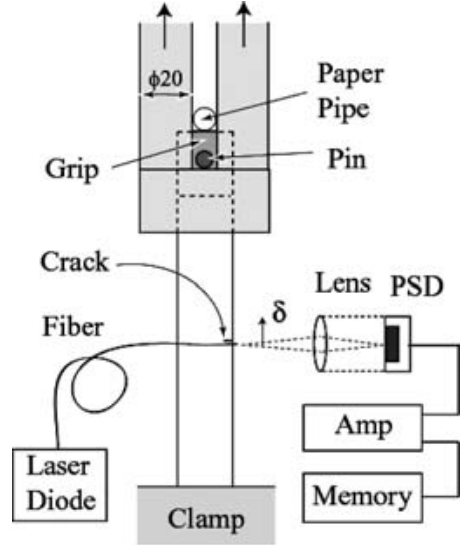

Fig. 2 Static loading method and displacement measurement by PSD.

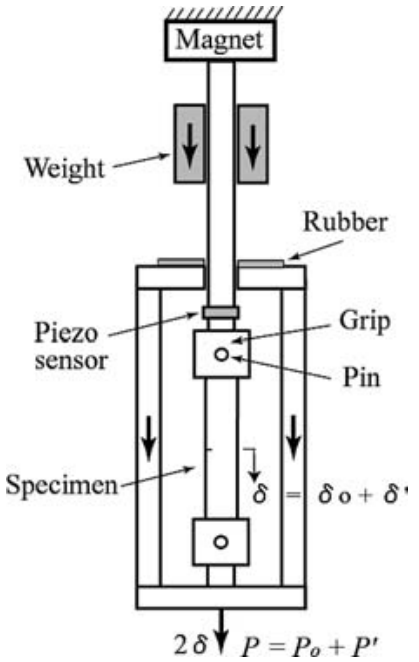

Fig. 3 Impact loading method. 


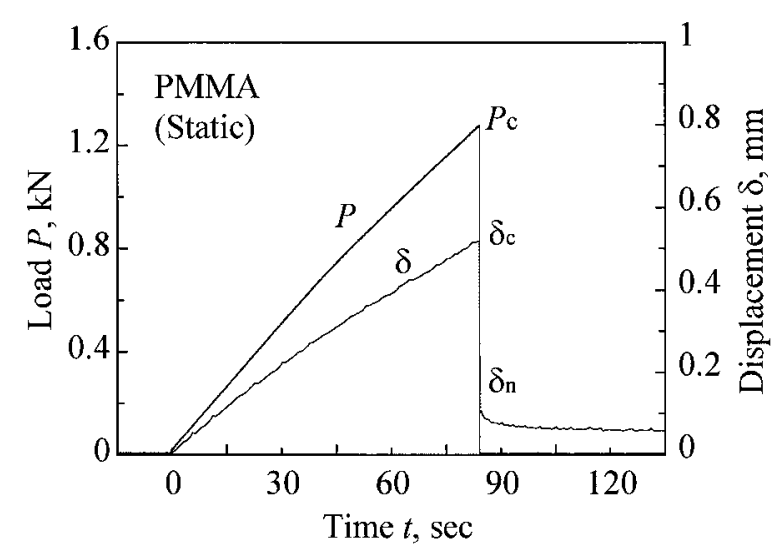

Fig. 4 Load $P$ and displacement $\delta$ as a function of time $t$ under static loading. (sampling time $\Delta \mathrm{t}=10 \mathrm{~ms}$ )

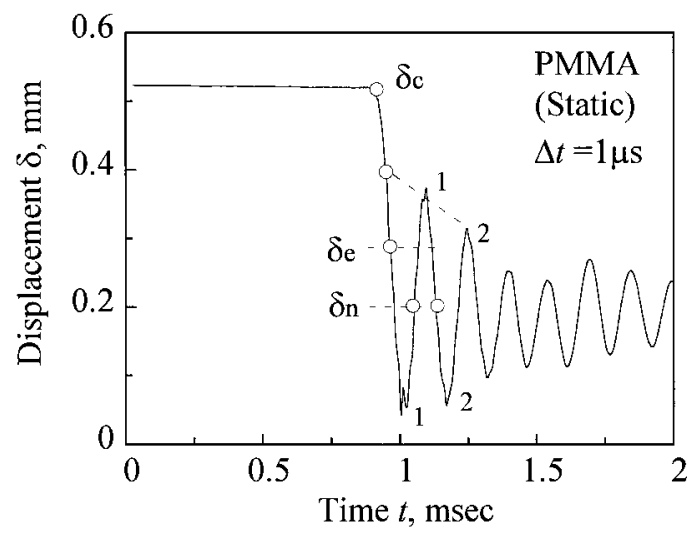

Fig. 5 Displacement $\delta$ versus time $t$ under static loading. (sampling time $\Delta \mathrm{t}=1 \mu \mathrm{s}$ )

$\delta^{\prime}$ に分けられる. Fig. 7 に $P$ と時間 $t$ の関係を示す. $P$ は $t$ とともに増加し, 試験片が破断すると $P_{\mathrm{c}}^{\prime}$ から急激に 低下した。このP-t波形から明らかなことは，金属枠の 上端に貼付けたゴムシートにより，衝撃時に発生する高 周波振動が軽減できたことである。

Fig. 8 に高速度変位計で測定した動的変位 $\delta^{\prime}$ と時間 $t$ の関係を示す， $\delta^{\prime}$ は $t$ とともに増加し， $\delta_{\mathrm{c}}^{\prime}$ で急激に低下 した。旮して， $\delta^{\prime}$ はその後，減衰を伴いながら振動した。 もし大きな非弾性変形が存在するならば，振動中心は Fig. 5 の $\delta_{\mathrm{n}}$ のように上側へシフトするはずである。しか し明確なシフトはみられない，すなわちこの結果は, 衝撃 負荷の場合には，非弾性変形が小さな值となることを示 唆している。同様な結果が他の試験片でも得られている。

Fig. 9 に衝撃引張条件下での $P^{\prime}-\delta^{\prime}$ 関係を示す。この結 果で示唆されていることは，ほぼ同じ初期き裂長さの 静的条件と比較して破断荷重が増加したことである (Fig. 6 参照).

\section{4 破壊エネルギの定義}

Fig. 10 に静的な初期荷重 $P_{0}$ が作用し，そのあと衝撃 負荷が作用する場合の荷重 $P$ と変位 $\delta$ の関係を示す，た だし $\delta$ は試験片中央点の変位を示す。一般に, $P-\delta$ の勾 配は静的と動的負荷では異なっている。しかし本研究で は，解析を容易にするため，さらに $P_{\mathrm{o}}$ が $P_{\mathrm{c}}$ より十分小

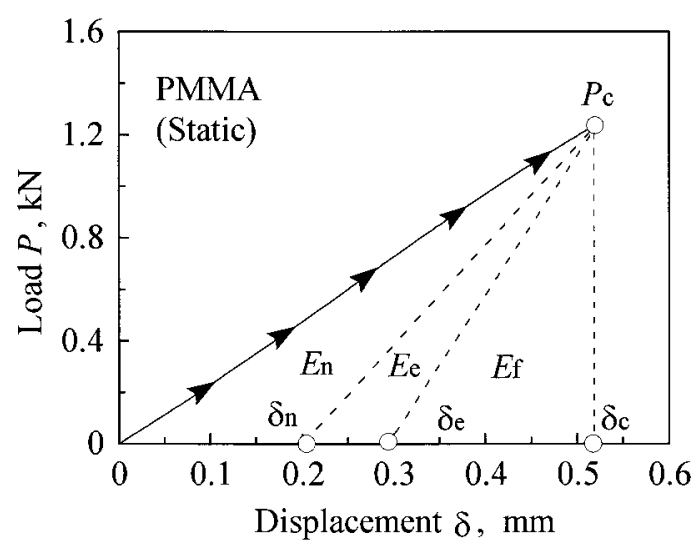

Fig. 6 Load $P$ versus displacement $\delta$ diagram under static loading.

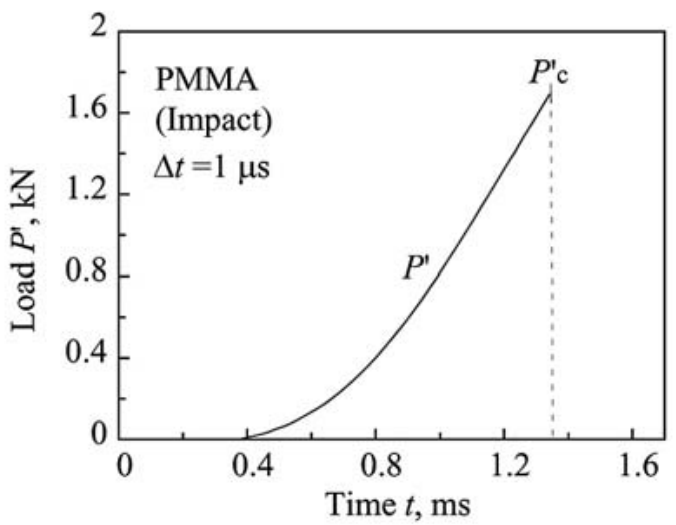

Fig. 7 Dynamic load $P$ versus time $t$ under impact loading. (sampling time $\Delta \mathrm{t}=1 \mu \mathrm{s}$ )

さい場合には大きな誤差が生じないものと仮定し，両者 の勾配を同一とした。このとき，外力が試験片の半分に なす仕事, すなわち外力仕事 $U_{\mathrm{ex}}$ は次式で与えられる.

$$
U_{\mathrm{ex}}=\frac{P_{\mathrm{c}} \delta_{\mathrm{c}}}{2}=\frac{\delta_{\mathrm{c}}^{\prime}\left(P_{\mathrm{o}}+P_{\mathrm{c}}^{\prime}\right)^{2}}{2 P_{\mathrm{c}}^{\prime}}
$$

ここで, $P_{\mathrm{c}}=P_{\mathrm{o}}+P_{\mathrm{c}}^{\prime}, \delta_{\mathrm{c}}=\delta_{\mathrm{c}}^{\prime} P_{\mathrm{c}} / P_{\mathrm{c}}^{\prime}$ である. な打静的負荷 の場合には， $U_{\mathrm{ex}}$ は $P_{\mathrm{c}}$ と $\delta_{\mathrm{c}}$ から決定した。

本研究では。破壊変形のプロセスが，き裂の進展，試 験片の破断, 学れに伴う弾性変形, 最後に非弾性変形の 残留という順序で生じるものと考える。そして， $U_{\mathrm{ex}}$ が Fig. 10 に示されるように以下の 3 つのエネルギ成分に分 離できるものと仮定した.8) 10)

$$
U_{\mathrm{ex}}=E_{\mathrm{f}}+E_{\mathrm{e}}+E_{\mathrm{n}}
$$

ここで $E_{\mathrm{f}}$ は全破壊エネルギの半分を表わす，すなわち $E_{\mathrm{f}}$ は, 破面 $\left(2 A_{\mathrm{s}}\right)$ の形成に必要な表面エネルギ，き裂から 放出される音響エネルギ，き裂周辺の温度上昇に寄与す る熱エネルギなど非可逆的な総エネルギの半分に対応す る。一方， $E_{\mathrm{e}}$ は試験片に蓄積される弾性的なひずみエネ ルギ， $E_{\mathrm{n}}$ は粘性や塑性ひずみなど破断後も試験片に残留 する非弾性的なエネルギに相当する。

本研究では, 弾性エネルギ $E_{\mathrm{e}}$, 非弾性エネルギ $E_{\mathrm{n}}$ を評 価するため, 以下のことを仮定した。(1) $E_{\mathrm{e}}$ は試験片が破 断すると全て運動エネルギに変換する。(2) 動的破壊で生 


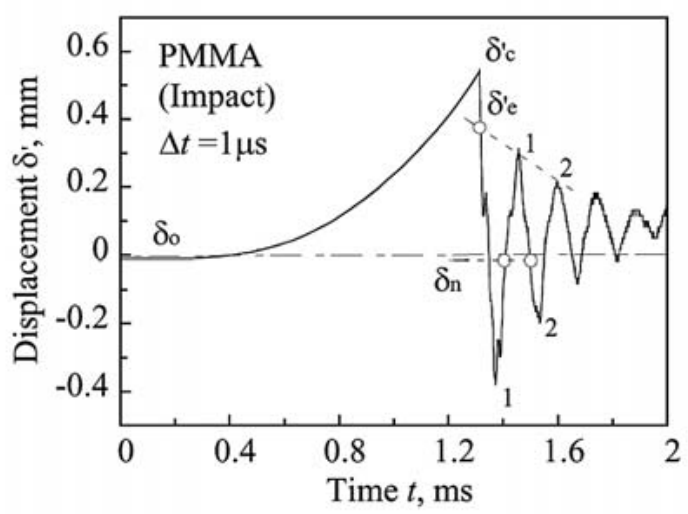

Fig. 8 Dynamic displacement $\delta^{\prime}$ versus time $t$ under impact loading. (sampling time $\Delta \mathrm{t}=1 \mu \mathrm{s}$ )

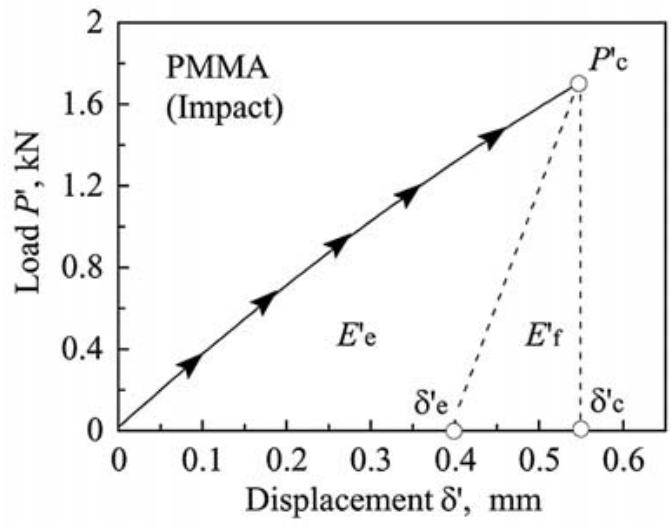

Fig. 9 Load $P^{\prime}$ versus displacement $\delta^{\prime}$ diagram under impact loading.

ビる除荷過程では粘弾性効果が無視できる.6.すすなお， $P_{\mathrm{c}}$ から破断直後の全変位 $\delta_{\mathrm{e}}$ や残留変位 $\delta_{\mathrm{n}}$ への変化が弾性的 とする (Fig. 10 参照)。午の結果, 次式が成立する。

$$
\frac{E_{\mathrm{e}}}{U_{\mathrm{ex}}}=\frac{\left(\delta_{\mathrm{e}}-\delta_{\mathrm{n}}\right)}{\delta_{\mathrm{c}}}, \frac{E_{\mathrm{n}}}{U_{\mathrm{ex}}}=\frac{\delta_{\mathrm{n}}}{\delta_{\mathrm{c}}}
$$

\section{$4 \cdot 1$ 非弾性エネルギ $\boldsymbol{E}_{\mathrm{n}}$}

非弾性エネルギ $E_{\mathrm{n}}$ を決定するためには破断直後の試 験片の残留変位 $\delta_{\mathrm{n}}$ を計測することが必要である。この計 測には前述のようにPSD センサを応用し，破断直後のき 裂近傍の変位 $\delta$ を求めた (Fig. 2 参照).

静的負荷では $\delta_{\mathrm{n}}$ 值は以下のように評価した。(1) デー タのサンプリングを $1 \mu \mathrm{s}$ 間隔で行った（Fig. 5 参照）. (2) 破断直後の振動の中心值を初期波形の 2 周期で求め た。（3）その中心值の平均を $\delta_{\mathrm{n}}$ として採用した。得られ た $\delta_{\mathrm{n}}$ 值を Fig. 11 に示す.ここでは 6 本の試験片から得 られた結果を破断荷重 $P_{\mathrm{c}}$ の関数として表示した。 $P_{\mathrm{c}}$ と ともに $\delta_{\mathrm{n}}$ が増加した。 この結果は，破断荷重が大きくな ると残留変位，すなわち非弾性エネルギ $E_{\mathrm{n}}$ が増加する ことを意味している。 $E_{\mathrm{n}}$ 值は，得られた $\delta_{\mathrm{n}}$ を式 (3)に代 入することにより求めた.

衝撃負荷での $\delta_{\mathrm{n}}$ 值は以下のように決定した。 Fig. 8 の $\delta^{\prime}-t$ 波形で明らかなことは, 破断直後の振動中心 $\left(\delta_{\mathrm{n}}\right.$ で 表示）が静的な初期変位 $\delta_{0}(=0.05 \mathrm{~mm})$ より小さくなつ

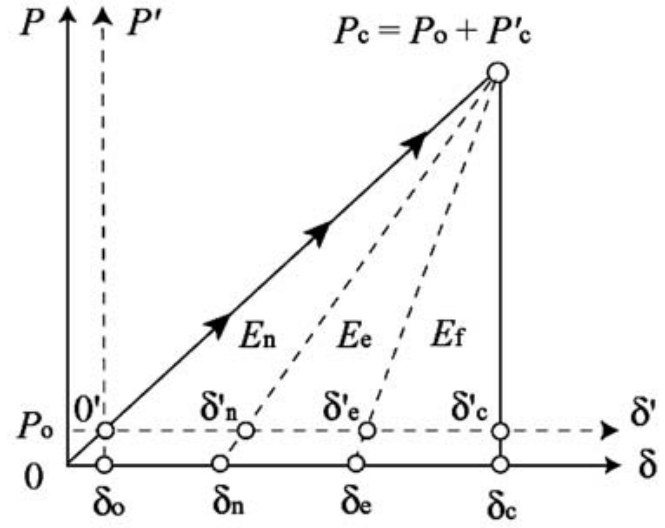

Fig. 10 Load $P$ versus displacement $\delta$ diagram with initial load $P_{0}$

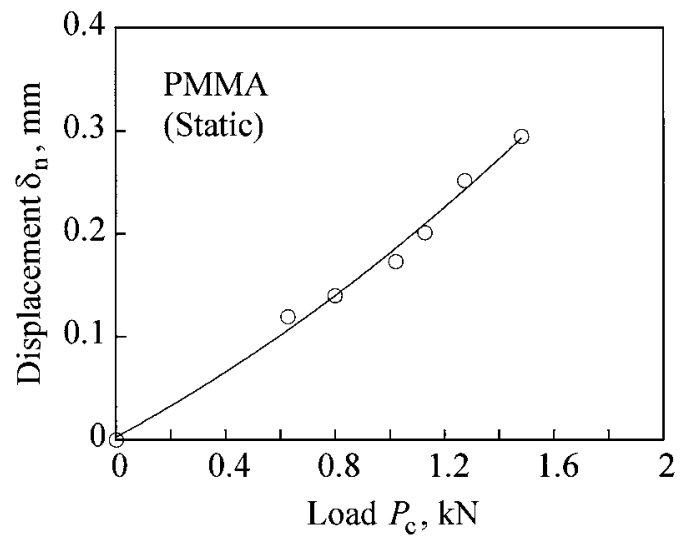

Fig. 11 Residual displacement $\delta_{\mathrm{n}}$ versus fracture load $P_{\mathrm{c}}$ under static loading.

ていることである。この結果は，破断後の振動中心が初 期荷重がない $P=0$ での值に近いこと，すなわち非弾性 変形が十分小さな值であることを意味している，同様な 結果は他の試験片でも得られた。そのため衝撃負荷条件 下では $E_{\mathrm{n}}=0$ を仮定した。

\section{$4 \cdot 2$ 弾性エネルギ $\boldsymbol{E}_{\mathrm{e}}$}

静的負荷装置のジグは，破断後に試験片の運動を拘束 しないように設計されている。午のため破断した試験上 部の最大飛しょう高さ $H_{\mathrm{e}}$ を計測することが可能となる. その計測結果を Fig. 12 に示す。ここでは $H_{\mathrm{e}}$ を破断荷重 $P_{\mathrm{c}}$ の関数として表示した. $H_{\mathrm{e}}$ は $P_{\mathrm{c}}$ の増加に伴い大きく なっている。すすなわちこの結果は，破断荷重が大きくな ると，試験片内部に蓄積される弾性エネルギが増加する こと，爷机に伴い飛しょう高さが大きくなることを示し ている。本研究では, 試験片に蓄積された弾性エネルギ $E_{\mathrm{e}}$ を次式で求めた。

$$
E_{\mathrm{e}}=m g H_{e}
$$

ここで， $m$ は負荷用グリップとピンを含めた試験片上部 の質量, $g$ は重力加速度を表す。

一方，使用した衝撃負荷装置では，破断時の試験片の 運動エネルギを直接計測することは容易ではない。このた め本研究では, 弾性エネルギ $E_{\mathrm{e}}$ を以下の方法で評価した (Fig. 8 参照)。(1) 試験片の破断後の変位波形 $\delta^{\prime}$ から 1 


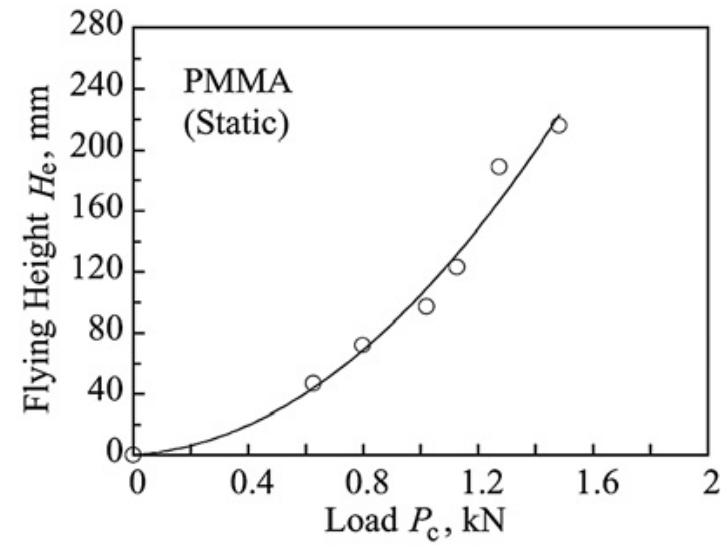

Fig. 12 Fiying heigth $H_{\mathrm{e}}$ versus fracture load $P_{c}$ under static loading.

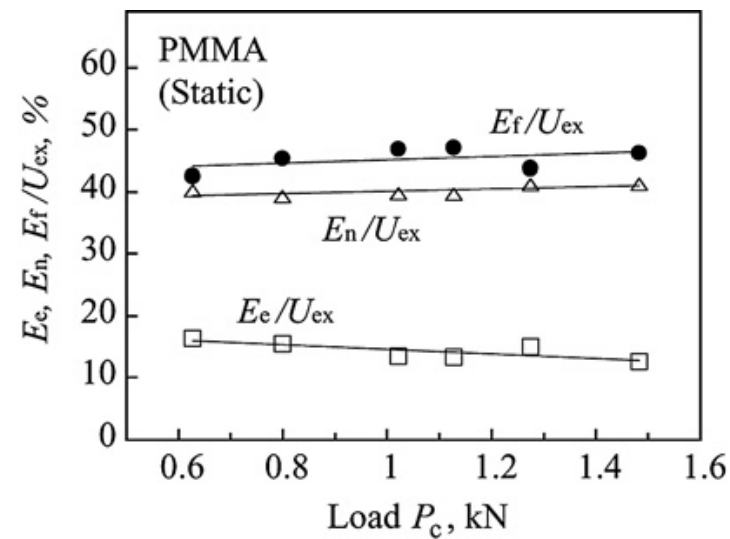

Fig. 13 Energy ratios $E_{\mathrm{e}} / U_{\mathrm{ex}}, E_{\mathrm{n}} / U_{\text {ex }}$ and $E_{\mathrm{f}} / U_{\mathrm{ex}}$ as a function of fracture load $P_{\mathrm{c}}$ under static loading.

周期目と 2 周期目の振幅を求める. (2) $1 ， 2$ 周期目の振 幅から減衰を考慮した直線（破線で表示）を決定する。 ただしこの減衰は，負荷軸への応力波の伝ぱによるもの とする。振幅を結ぶ淔線と変位曲線 $\delta^{\prime}$ との交点 $\delta_{\mathrm{e}}{ }^{\prime}$ を求 める。（4）そして， $\delta_{\mathrm{e}}$ は次式で求めた (Fig. 10 参照).

$$
\delta_{\mathrm{e}}=\frac{\delta_{\mathrm{e}}^{\prime}\left(P_{\mathrm{o}}+P_{\mathrm{c}}^{\prime}\right)}{P_{\mathrm{c}}^{\prime}}
$$

さらに $E_{\mathrm{e}}$ 值は, 得られた $\delta_{\mathrm{e}}$ を式 (3)に代入して求めた.

静的負荷の場合でも破断直後の振幅から $E_{\mathrm{e}}$ 值を近似 的に評価することが可能である。ただし同一荷重值に対 して動的変位は静的変位の 2 倍となることが理論的に示 されている。そのため静的破断変位との比をとる場合に は，Fig. 5 に示すように振幅，すなわち動的変位の半分 值を用いることが必要となる. Fig. 5 の $\delta_{\mathrm{e}}$ 值から弾性エ ネルギと外力仕事の比 $E_{\mathrm{e}} / U_{\mathrm{ex}}$ を求めると約 $18 \%$ となり, 飛しょう高さ $H_{\mathrm{e}}$ から得られた約 $15 \%$ とほほ同じ值となる.

\section{$4 \cdot 3$ 破壊エネルギ $\boldsymbol{E}_{\mathrm{f}}$}

得られた外力仕事 $U_{\mathrm{ex}}$, 弾性エネルギ $E_{\mathrm{e}}$, 非弾性エネル ギ $E_{\mathrm{n}}$ を式 (2)に代入することにより $E_{\mathrm{f}}$ 值を求めた。静的 負荷での結果を Fig. 13 に，衝撃負荷での結果を Fig. 14 に示す。ただしここでは，各エネルギ值と外力仕事の比， すなわち, $E_{\mathrm{e}} / U_{\mathrm{ex}}, E_{\mathrm{n}} / U_{\mathrm{ex}}, E_{\mathrm{f}} / U_{\mathrm{ex}}$ を破断荷重 $P_{\mathrm{c}}$ の関

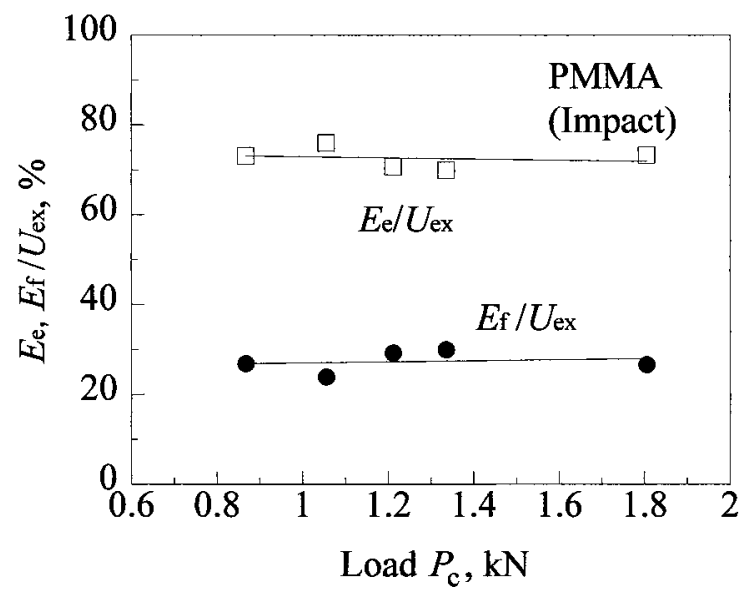

Fig. 14 Energy ratios $E_{\mathrm{e}} / U_{\mathrm{ex}}$ and $E_{\mathrm{f}} / U_{\mathrm{ex}}$ as a function of fracture load $P_{\mathrm{c}}$ under impact loading.

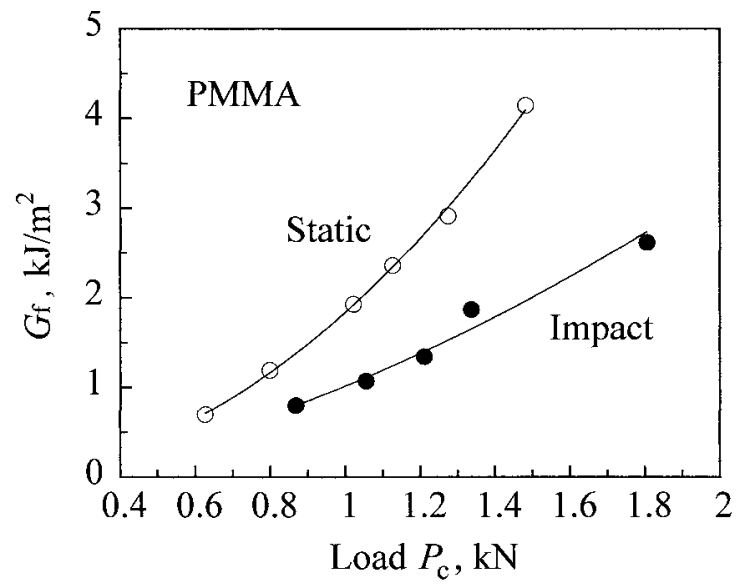

Fig. 15 Energy release rate $G_{\mathrm{f}}$ versus fracture load $P_{\mathrm{c}}$ under static and impact loadings.

数として表示した。得られた結果を以下に示す. 静的負荷（Fig. 13 参照）では，(1) $E_{\mathrm{n}} / U_{\mathrm{ex}}$ は約 $40 \%$ の 一定值，(2) $E_{\mathrm{e}} / U_{\mathrm{ex}}$ は， $P_{\mathrm{c}}$ が小さいところでは約 $15 \%$, また比較的に大きなところでは約 $13 \% ，(3) E_{\mathrm{f}} / U_{\mathrm{ex}}$ は若 干変化するものの, 約 $45 \%$ の一定值となった.

一方，衝撃負荷（Fig. 14 参照）では，(1) $E_{\mathrm{n}} / U_{\mathrm{ex}}$ はほ ぼ零, (2) $E_{\mathrm{e}} / U_{\mathrm{ex}}$ は, 約 $73 \%,(3) E_{\mathrm{f}} / U_{\mathrm{ex}}$ は, 約 $27 \%$ となっ た.すなわち静的と衝撃負荷では，エネルギ比が大きく 異なることが示されている.

\section{$4 \cdot 4$ エネルギ解放率 $G_{\mathrm{f}}$}

エネルギ解放率 $G_{\mathrm{f}}$ を次式で評価した。

$$
G_{\mathrm{f}}=\frac{E_{\mathrm{f}}}{A_{\mathrm{s}}}
$$

ここで $A_{\mathrm{s}}$ は破面の面積を表す。式 (6)から導かれた $G_{\mathrm{f}}$ 值 を Fig. 15 に示す。静的および衝撃負荷条件下において, $G_{\mathrm{f}}$ は一定值でなく, $P_{\mathrm{c}}$ とともに増加した。これは $P_{\mathrm{c}}$ の 増加に伴い， $E_{\mathrm{f}}$ 值が大きくなることを意味している。 ま た衝撃時の $G_{\mathrm{f}}$ 值が静的值より小さくなっている。この結 果は, 衝撃条件下では運動エネルギ, すなわち弾性エネ ルギ $E_{\mathrm{e}}$ が大きくなり，これに伴い対応する $E_{\mathrm{f}}$ が小さく なることを示唆している. 


\section{5 結}

言

静的および衝撃引張試験装置を用いて PMMA 樹脂の ぜい性破壞実験を行なった。試験片に作用する荷重と変 位より外力仕事 $U_{\mathrm{ex}}$, 破断直後の残留変位より非弾性工 ネルギ $E_{\mathrm{n}}$ を求めた。一方, 弾性エネルギ $E_{\mathrm{e}}$ は, 静的負 荷では試験片の破断後の飛しょう高さより, 衝撃負荷で は試験片破断直後の振幅より決定した。破壊エネルギ $E_{\mathrm{f}}$ は, $U_{\mathrm{ex}}, E_{\mathrm{n}}, E_{\mathrm{e}}$ より求め, エネルギ比 $E_{\mathrm{e}} / U_{\mathrm{ex}}, E_{\mathrm{n}} / U_{\mathrm{ex}}$, $E_{\mathrm{f}} / U_{\mathrm{ex}}$ を評価した。さらに破面の面積 $A_{\mathrm{s}}$ を用いて，工 ネルギ解放率を $G_{\mathrm{f}}=E_{\mathrm{f}} / A_{\mathrm{s}}$ で求め, 破断荷重 $P_{\mathrm{c}}$ との対 応関係を検討した。 そして以下の結果を得た。

（1） $E_{\mathrm{e}} / U_{\mathrm{ex}}, E_{\mathrm{n}} / U_{\mathrm{ex}}, E_{\mathrm{f}} / U_{\mathrm{ex}}$ 值は，負荷方法により 大きく異なった。

（2） $E_{\mathrm{n}} / U_{\mathrm{ex}}$ 值は，静的負荷で約 $40 \%$ ，衝撃負荷でほ ぼ零となった。

(3) $E_{\mathrm{e}} / U_{\mathrm{ex}}$ は, 静的より衝撃負荷で大きな値を示した.

（4） $E_{\mathrm{f}} / U_{\mathrm{ex}}$ 值は，静的負荷で約 $45 \%$, 衝撃負荷では約 $27 \%$ となった。

（5） $P_{\mathrm{c}}$ が大きくなると $G_{\mathrm{f}}$ 值は増加した.

（6） $G_{\mathrm{f}}$ は静的より衝撃負荷で小さな值を示した.

\section{参 考 文 献}

1) J. G. Williams, "Fracture Mechanics of Polymers" (1984) Ellis Horwood Limited.

2) A. S. Kobayash, "Handbook on Experimental Mechanics", pp.430-500 (1987) Prentice-Hall.

3) J. W. Dally and A. Shukla, "Energy Loss in Homalite 100 during Crack Propagation an Arrest", Engineering Fracture Mechanics, Vol.13, pp.807-817 (1980).
4) A. Shukla and H. Nigam, "Note on the Stress Intensity Factor and Crack Velocity Relationship for Homalite 100”, Engineering Fracture Mechanics, Vol.25, pp.91-102 (1986).

5 ) S. Suzuki, H. Homma and R. Kusaka, "Pulsed Holographic Microscopy as a Measurement Method of Dynamic Fracture Toughness for Fast Propagating Cracks”, Journal of the Mechanics and Physics of Solids, Vol.36-6, pp.631-653 (1988).

6 ) K. Arakawa, D. Nagoh and K. Takahashi, "Dynamic Crack Propagation and Unloading Behavior of Brittle Polymers”, International Journal of Fracture, Vol.96, pp.347-360 (1999).

$7)$ K. Arakawa, T. Mada and K. Takahashi, "Correlations among Dynamic Stress Intensity Factor, Crack Velocity and Acceleration in Brittle Fracture”, International Journal of Fracture, Vol.105, pp.311-320 (2000).

8) K. Arakawa and T. Mada, "Measurement of Brittle Fracture Energy in PMMA (2nd Report, Application of High-Speed Extensometer", Transactions of the Japan Society of Mechanical Engineers, Series A, Vol.70, No.695, pp.936-940 (2004).

9) K. Arakawa and T. Mada, "Measuring Fracture Energy in a Brittle Polymeric Material”, Experimental Mechanics, Vol.46, pp.347-353 (2006).

10) K. Arakawa, T. Mada, J. Takahashi, M. Todo and S. Ooka, "Effect of Rubber Particle Size on Impact Tensile Fracture Behavior of MBS Resin”, Journal of the Society of of Material Science, Japan, Vol.56, No.4, pp.371-376 (2007). 